\title{
A Study on Interest and Attitude of the Higher Secondary School Students towards English Curriculum in Khargone Taluka
}

\author{
Miss. Shabina Khan \\ Asst. Professor, Shri Kanwartara Institute for Teacher's Training, Shri Nagar Colony, Mandleshwar, Tehsil- \\ Maheshwar, Dist.Khargone (M.P.) India 451221
}

\begin{abstract}
The main aim of this study is to investigate the interest and attitude of higher secondary school students towards English curriculum in Khargone taluka. In the present research paper the investigator tried to compare the attitude of rural and urban students towards English curriculum. But this results are not the last truth. I hoped that in the suggestions and the results will be helpful for the development of the situation of the English curriculum in the schools in present time.
\end{abstract}

Keywords:- Interest, Attitude, English Curriculum, secondary school.

\section{INTRODUCTION}

Education takes the personality of person as important In 1964-66 education management told "In present time India's future is developing in the classrooms. For the development of the students we must give proper training to the trainee. So with help of it they can do welfare for their country and also for their society. Because the development of the society is depended on the education, and this type of education can be given in the schools. it is rightly said that, in the schools undeveloped live person is turned in to the well developed in the right personality.

\section{Statement of the problem \\ A STUDY ON INTEREST AND ATTITUDE OF THE HIGHER SECONDARY SCHOOL STUDENTS TOWARDS ENGLISH CURRICULUM IN KHARGONE TALUKA}

\section{Objectives of the Research}

Before researching on any problem it is needed to determine the objectives of the problem. Because without this determination we cannot achieve the goal. Thus, there are some objectives.

To identify the interest of the students in the English language.

To find out the attitude of the students towards the English language.

To compare the attitudes of male \& female students towards English curriculum.

To compare the attitudes of rural \& urban students towards English curriculum.

To find out the learning difficulties of students.

To give suggestions for improvement of the English curriculum.

\section{Limitations of the Research}

Because of the time limitation $\&$ available sources we limit our study to one small part of the taluka.

It is limited only for the $9^{\text {th }}$ standard.

It is limited in the Khargone taluka's four higher secondary schools.

It is limited in the two schools of the rural and two school of urban area.

There were only 16 male \& 16 female students are covered under the research.

\section{Research Hypotheses.}

Investigator is used zero hypothesis in the present research.

The identification of the interest of the students in the English language will be taken care of .

The positive attitude of the students towards the English language will be useful.

The comparison of the attitudes of male \& female students towards English curriculum will be helpful for encouragement.

- $\quad$ The comparison of the attitudes of rural \& urban students towards

English curriculum will be useful for encouragement.

The identification of the learning difficulties of students will be useful.

The suggestions for improvement of the English curriculum will be useful for improvement of attitude of the students towards the English curriculum.

Researches Done in India.

In the India there are many research were done during fifty years.

(A) SHRIVASTRA - (1950) :- He had done a study on attitude of the teachers towards their profession, he had found that attitude of the teachers towards their profession is important.

(B) NARAYAN SINGH - (1986) :- He had done a study of the teacher towards History education. He had found that the teacher of history thought that their place in the society is title.

\section{Researches Done Abroad.}

Present section indicates that some researches were done abroad. They are as the following. 
(A) HARPER MAHODAY - (1927) :- He had done a study on attitude of the U.S. teachers. He had found that teachers were never clear on the problems of the society. They always followed their old methods of teaching. They heisted to accept the new methods.

(B) NANDAN TARESA - (1994) :- He had done a study on the attitude of the teachers of the science. He used a questionnaire for the research, than he had found that most of the schoolyard teachers attitudes are positive.

\section{Sample of the research}

The area of the present research paper is limited because of the time limitation \& available sources. We limited our study to one small block of the khargone taluka.

- It is limited only for the $9^{\text {th }}$ standard.

- $\quad$ It is limited in the khargone taluka's four higher secondary school.

- $\quad$ It is limited in the two schools of the rural and two school of urban area.

- $\quad$ There were only 16 male \& 16 female students are covered under the research.

Keeping all the points in the mind there were 32 male \& 32 female students selected as the sample.

\begin{tabular}{|c|c|c|c|}
\hline S.No. & Name of the school & STD. & Total \\
\hline \multicolumn{4}{|c|}{ URBAN } \\
\hline 1 & Shri Krishna Colony Khargone & 9 & 16 \\
\hline 2 & Vidya Vijay Mandir, Khargone & 9 & 16 \\
\hline \multicolumn{4}{|c|}{ RURAL } \\
\hline 1 & Govt. Boys High School Khargone & 9 & 16 \\
\hline 2 & Govt. Girls High School Khargone & 9 & 16 \\
\hline & Total Students. & - & 64 \\
\hline
\end{tabular}

\section{Collection of figures of the research paper}

The research paper is moving towards it's target from the completing its steps and stages. So, the investigator has starting the collection of the data after selecting the sample. This work has been completed with the investigators evaluation. After completing the test all the test all the data are collected.

\section{Data collection}

After collecting the data the main work is to do the data analysis. data collection the investigator had done the data analysis with the help of the attitude of the students towards the English curriculum. After data analysis the investigator got the proper way towards the solution of the problem.

\section{STATISTICAL TECHNIQUES}

Mean, S.D., Percentage and ' $t$ ' test were used to analyze the collected data and verify the hypotheses.

Analysis and Interpretation

1 Attitude of the students towards English curriculum. This is shown in table No. 1

Table No. - 1: Attitude of the students towards English curriculum.

\begin{tabular}{|c|c|c|c|c|c|}
\hline Students & $\mathrm{N}$ & No. of statements & Total Score & Average & Per (\%) \\
\hline Male & 32 & 41 & 205 & 146.50 & 71.46 \\
\hline Female & 32 & 41 & 205 & 141.91 & 69.22 \\
\hline Total & $\mathbf{6 4}$ & $\mathbf{4 1}$ & $\mathbf{2 0 5}$ & $\mathbf{1 4 4 . 2 0}$ & $\mathbf{7 0 . 3 4}$ \\
\hline
\end{tabular}

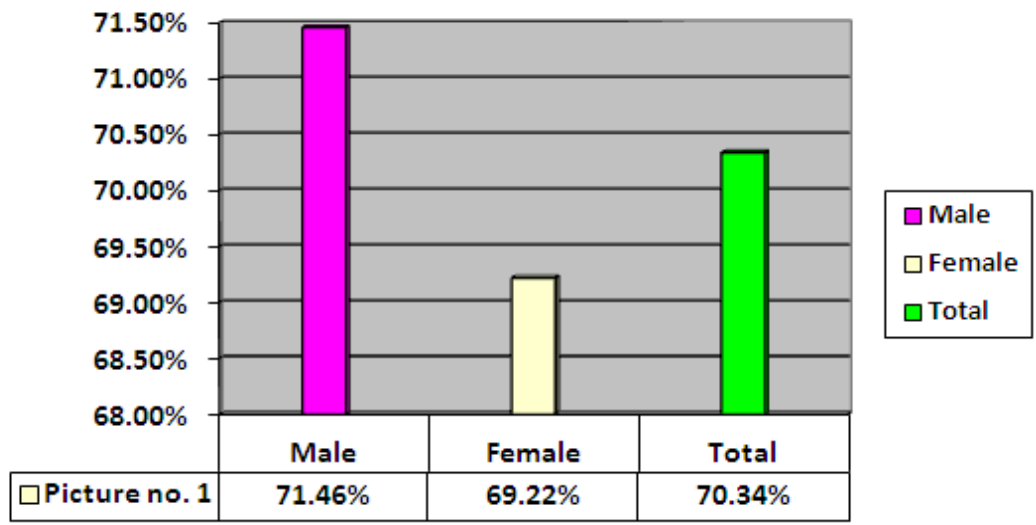

Percentage of attitude of the students towards the English curriculum

There was a test taken of the attitude towards English curriculum of all the students. It is seen from the table No. 1 that the attitude towards English curriculum was $70.34 \%$ which is above $60 \%$. So, the attitude of the rural male and female student towards English curriculum was positive. The attitude of the rural male and female students towards English curriculum is $71.46 \%$ and $69.22 \%$ which is above $60 \%$. So, the attitude towards English curriculum was positive. It is seen 
from the table No. 1 that the attitude of male students was more than the female students towards English curriculum. For the proof of it the investigator had calculated the Mean, S.D. ' $t$ ' value which was shown in the table No. 1

\section{Comparison of attitude of male \& female students towards English curriculum.}

Table No. - 2: The mean, standard deviation, 't' value of the attitude of male \& female

\begin{tabular}{|c|c|c|c|c|}
\hline Sex & N & Mean & S.D. & 't' value \\
\hline Male & 32 & 146.50 & 6.91 & 2.32 \\
\cline { 1 - 3 } Female & 32 & 141.91 & 8.16 & \\
\hline
\end{tabular}

$D f=62,0.05$ base ' $t$ ' value 2.00 at 0.05 level

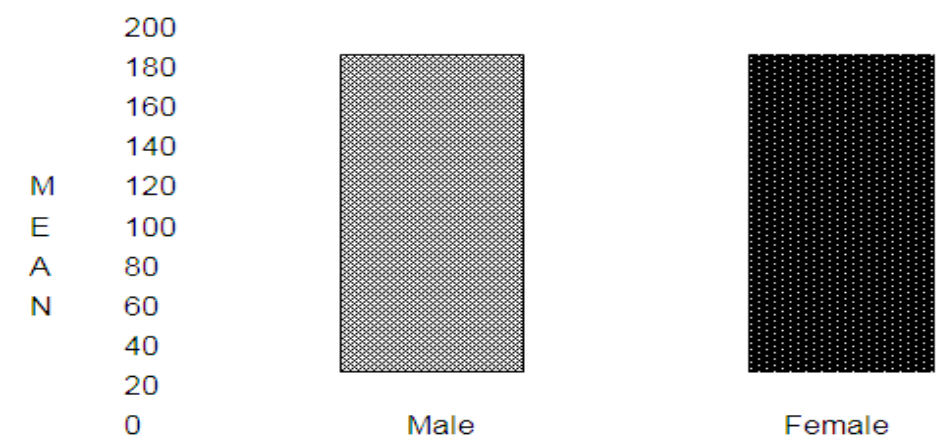

Picture No. -2 : Comparison of mode of attitude of male $\&$ female students

The investigator had done the comparison of attitude of male \& female students towards English curriculum. The investigator found the distance in the both ' $t$ ' values. The investigator found 2.32 ' $t$ ' value of the attitude which was above the base value. We can see that the attitude of male students was more favourable/ positive than the female students towards English curriculum. This was shown in the table No. 2

3 Attitude of rural \& urban students towards English curriculum.

To get above objective the investigator had collected the figures from the attitude evaluation. Than he founded the percentages of the figures, which was shown in the table No. 3.

Table No. -3 : Attitude of rural \& urban students towards English curriculum

\begin{tabular}{|c|c|c|c|c|c|}
\hline Area & N & No. of statements & Total Score & Average & Per (\%) \\
\hline Rural & 32 & 41 & 205 & 144.00 & 70.24 \\
\hline Urban & 32 & 41 & 205 & 144.41 & 70.44 \\
\hline Total & 64 & 41 & 205 & 142.20 & 70.34 \\
\hline
\end{tabular}

$\begin{array}{ll} & 100 \\ & 90 \\ & 80 \\ & 70 \\ \mathrm{M} & 60 \\ \mathrm{E} & 50 \\ \mathrm{~A} & 40 \\ \mathrm{~N} & 30 \\ & 20 \\ & 10 \\ & 0\end{array}$

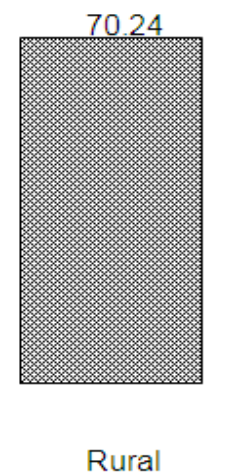

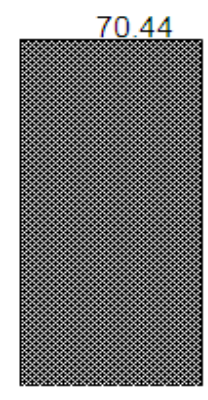

Urban

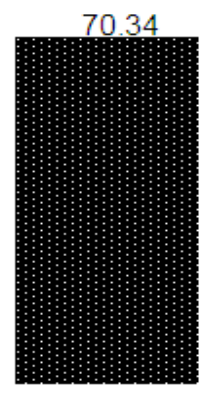

Total

Picture No. -3 : Percentages of attitude of rural \& urban students towards English curriculum.

There was a research on the attitude of rural \& urban students towards English curriculum. The attitude of the rural \& urban students towards English curriculum is $70.24 \%$ which was above $60 \%$. The attitude of the rural urban and rural students towards English curriculum was positive. There is no difference between the attitude of the rural urban and rural students towards English curriculum 


\section{Comparison of attitudes of rural \& urban students towards English curriculum}

To investigate the above objective the investigator had collected the figures of attitude of rural \& urban students towards English curriculum on the basis of them he counted the mean, S.D., and 't' value, which was shown in the table no. 4. The investigator had done the comparison of attitude of rural \& urban students towards English curriculum. The investigator did not get distance between ' $t$ ' value of attitudes of rural \& urban students towards English curriculum. That matter was shown in the picture No. 4 so, we can say that the attitudes of rural \& urban students towards English curriculum

5. To achieve the above goal the investigator gave the questionnarie to the rural \& urban students, He found the percentages of them. Which was shown in the table No. 5.

Table No. - 5: Attitude of rural \& urban male students towards English curriculum

\begin{tabular}{|c|c|c|c|c|c|c|}
\hline Area & & $\mathrm{N}$ & No. of statements & Total score & Average & Per $(\%)$ \\
\hline Urban statements & & 16 & 41 & 205 & 145.50 & 70.98 \\
\hline Rural statements & & 16 & 41 & 205 & 147.50 & 71.95 \\
\hline Total & & 30 & 41 & 205 & 146.5 & 71.46 \\
\hline & & 100 & 70.98 & 71.95 & 71.4 & \\
\hline & & 90 & & & & \\
\hline & & 80 & & & & \\
\hline & & 70 & & & & \\
\hline & $\mathrm{P}$ & 60 & & & & \\
\hline & $E$ & 50 & & & & \\
\hline & $\mathrm{R}$ & 40 & & & & \\
\hline & $\%$ & 30 & & & & \\
\hline & & 20 & & & & \\
\hline & & 10 & & & & \\
\hline & & 0 & Urban & Rural & Total & \\
\hline
\end{tabular}

Picture no. 5: Percentage of rural \& urban male students

There was the test of rural \& urban male students attitudes English curriculum. The attitudes of the rural urban and rural students attitudes English curriculum were $70.24 \%$ and $70.44 \%$ which was above $60 \%$ and $70.98 \%$ which was above $60 \%$. So the attitude of the rural and urban students attitudes English curriculum was positive. There is nothing distance between the attitude of the rural and urban students attitudes English curriculum.

6. Comparison of attitudes of rural \& urban male students towards English curriculum.

There was the test of rural \& urban male students towards English curriculum for the calculation of the mean, S.D. and ' $t$ ' value. Which was shown in the table No. 6.

Table No. - 6: The mean, standard deviation, ' $t$ ' value of the rural $\&$ urban male students

\begin{tabular}{|c|c|c|c|c|}
\hline Area & $\mathrm{N}$ & Mean & S.D. & 't' value \\
\hline Urban & 16 & 145.50 & 7.05 & 0.82 \\
\cline { 1 - 3 } Rural & 16 & 147.50 & 6.76 & \\
\hline
\end{tabular}

$\mathrm{Df}=300.05$ base 't' value 2.04

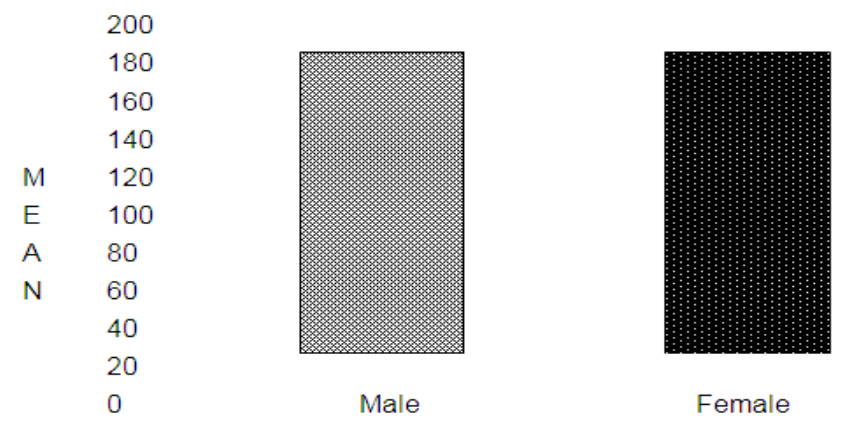

Picture No. -6 : Comparison of mode of rural \& urban male students

There was a comparison of attitude of the rural \& urban male students towards English curriculum. The investigator showed the comparison of attitudes of rural \& urban male students towards English curriculum. The ' $t$ ' value was 0.82 which was above the base of the value 0.05 . There was no distance of attitude of the rural $\&$ urban male students towards English curriculum. This is shown in the picture No. 3. The comparison of mode of the rural \& urban male students 
toward English curriculum was shown by the investigator. So, it can be said that the attitude of the rural \& urban male students towards English curriculum was the same.

7. Attitudes of rural \& urban female students towards English curriculum.

To achieve the above goal the investigator gave the questionnnarie to the rural \& urban students, He got the data, then he found the percentages of them which was shown in table No. 7.

Table No. - 7 : Attitude of rural \& urban female students towards English curriculum

\begin{tabular}{|c|c|c|c|c|c|}
\hline Area & $\mathrm{N}$ & No. of statements & Total score & Average & Per (\%) \\
\hline Urban students & 16 & 41 & 205 & 141.31 & 68.93 \\
\hline Rural students & 16 & 41 & 205 & 142.50 & 69.51 \\
\hline Total & 32 & 41 & 205 & 141.91 & 69.22 \\
\hline
\end{tabular}

$\begin{array}{cl} & 100 \\ & 90 \\ & 80 \\ & 70 \\ \mathrm{P} & 60 \\ \mathrm{E} & 50 \\ \mathrm{R} & 40 \\ \% & 30 \\ & 20 \\ & 10 \\ & 0\end{array}$

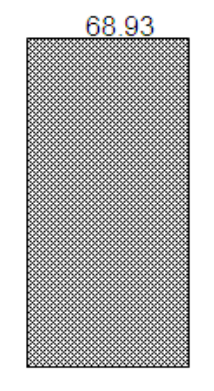

Urban
Students

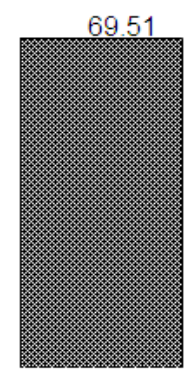

Rural

Students

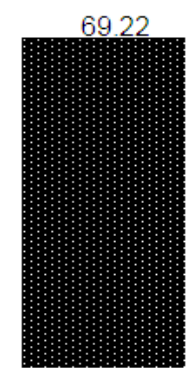

Total

Picture No. - 7 : Percentage of rural \& urban female students.

There was a difference of the attitudes of rural \& urban female students towards English curriculum. The investigator found that the attitude of the rural \& urban female students towards English curriculum was $69.51 \%$ and $68.93 \%$ which was above $60 \%$. So the investigator found that the attitude of the rural \& urban female students towards English curriculum was positive. On the base of the percentage the investigator found that the attitude of the rural $\&$ urban female students towards English curriculum was the same which was shown in table No. 7.

\section{Comparison of attitude of rural \& urban female students towards English curriculum.}

The investigator found the mean, S.D. and ' $t$ ' value of the attitude of the rural \& urban female students towards English curriculum as the following.

Table No. -8 : The mean, standard deviation, 't' value of rural \& urban female students

\begin{tabular}{|c|c|c|c|c|}
\hline Area & M & Mean & S.D. & 't' value \\
\hline Rural students & 16 & 141.31 & 9.02 & 0.36 \\
\cline { 1 - 3 } Urban students & 16 & 142.50 & 9.87 & \\
\hline
\end{tabular}

$\begin{array}{ll} & 200 \\ & 180 \\ & 160 \\ & 140 \\ \text { M } & 120 \\ \text { E } & 100 \\ \text { A } & 80 \\ \text { N } & 60 \\ & 40 \\ & 20 \\ & 0\end{array}$

141.31

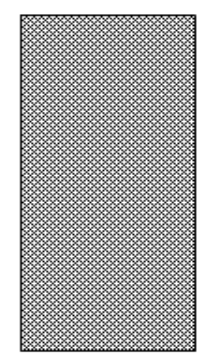

Rural
142.50

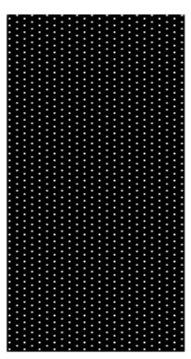

Urban

Picture No. - 8 : Comparison of mode of rural \& urban female students.

The investigator had shown the comparison of attitude of rural \& urban female students. With the help of that figures he got the ' $t$ ' value. The investigator had found ' $t$ ' value as 0.36 which was lower than the base value. So, there was no difference between attitudes of rural \& urban female students towards English curriculum which was shown in the picture No. 6 so, it can be said that the attitudes of rural \& urban female students towards English curriculum were the same. 
9. Attitudes of rural male female students towards English curriculum.

To achieve the above goal, the investigator gave the questionnaire to the rural \& urban female students. He got the data then he found the percentages of them. Which was shown in the table No. 9.

Table No. - 9 : Attitude of rural male female students towards English curriculum

\begin{tabular}{|c|c|c|c|c|c|}
\hline Students & $\mathrm{N}$ & No. of statements & Total score & Average & Per (\%) \\
\hline Male & 16 & 41 & 205 & 147.50 & 71.95 \\
\hline Female & 16 & 41 & 205 & 141.31 & 68.93 \\
\hline Total & 32 & 41 & 205 & 144.41 & 70.44 \\
\hline
\end{tabular}

$\begin{array}{cc} & 100 \\ & 90 \\ & 80 \\ & 70 \\ \mathrm{P} & 60 \\ \mathrm{E} & 50 \\ \mathrm{R} & 40 \\ \% & 30 \\ & 20 \\ & 10\end{array}$

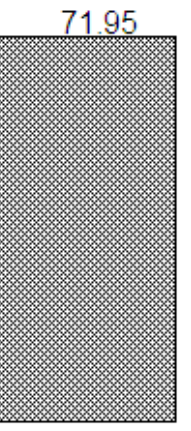

Male

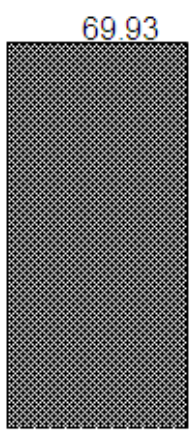

Female

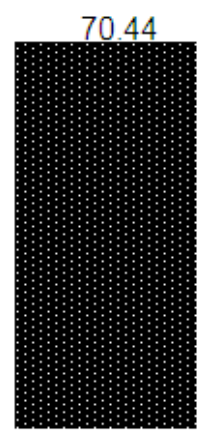

Total

Picture No. - 9 : Percentages of rural male \& female students.

The researcher investigated the attitudes of rural male \& female students towards English curriculum. The researcher found that the attitudes of the rural male female students towards English curriculum were 71.95\% and 69.93\% which was above $60 \%$. So, the researcher found that the attitudes of the rural male female students towards English curriculum were positive. On the base of the percentage the researcher found that the Attitudes of the rural male female students towards English curriculum were same. Which was shown as follows.

\section{Comparison of attitudes of rural male female students towards English curriculum}

To achieve the above goal the researcher gave the questionnaire to the rural male and female students. He got the data, then he found the mean, S.D., and 't' value of rural male \& female students. Which was shown in table No. 10

Table No. - 10 : The mean, S.D., 't' value of rural male \& female students

\begin{tabular}{|c|c|c|c|c|}
\hline Students & $\mathrm{N}$ & Mean & S.D. & 't' value \\
\hline Male & 16 & 147.50 & 7.05 & 2.17 \\
\hline Female & 16 & 141.31 & 9.02 & \\
\hline
\end{tabular}

$\begin{array}{ll} & 200 \\ & 180 \\ & 160 \\ & 140 \\ \mathrm{M} & 120 \\ \mathrm{E} & 100 \\ \mathrm{~A} & 80 \\ \mathrm{~N} & 60 \\ & 40 \\ & 20 \\ & 0\end{array}$
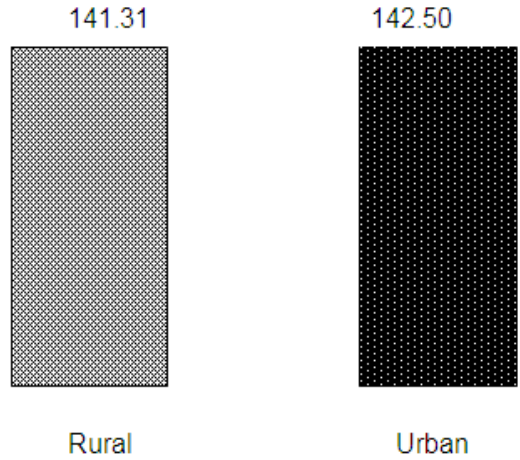

Picture No. - 10 : Comparison of mode of Attitudes of rural \& urban female students.

The researcher compared the attitude of rural male female students towards English curriculum. The investigator found that the attitude of the rural male \& female students towards English curriculum was quite different. So, the investigator found that the Attitudes of rural male female students towards English curriculum were positive. On the base of the percentage the researcher found that the Attitudes of rural male female students towards English curriculum were more. Which was shown as follows.

\section{Findings-}

(a) The attitude of the students towards English curriculum.

The attitude of the students towards English curriculum was suitable. 
The attitude of the all students was $70.34 \%$. So, the attitude of the students towards English curriculum positive.

(b) Comparison of the attitude of the male and female students towards English curriculum.

The attitude of the male students towards English curriculum was $71.46 \%$ and the attitude of the male students towards English curriculum was $69.22 \%$ After the comparison, it can be said that the attitude of the male students was more than the female students attitude towards English curriculum.

(c) Result of the male and female students on the bases of the mean, S.D. and ' $t$ ' value.

The mode of the attitude of the male students towards English curriculum was 146.50 and the mode of the attitude of the female students towards English curriculum was 141.91. There was a remarkable difference between the mode of both.

While the ' $t$ ' value of the attitude of the male and female students towards English curriculum was 2.32 which was more than the value 0.05 .

(b) The attitude of the rural and urban students towards English curriculum.

The attitude of the rural and urban students towards English curriculum was $70.44 \%$ and 70.24 . There was no difference between the attitude of the rural and urban students towards English curriculum.

(e) Results of the rural and urban students towards English curriculum on the bases of the mean, S.D. and ' $t$ ' value. The mode of the rural and urban students towards English curriculum was 147.50 and 145.50. There was no difference between them the bases of the mean.

There was no difference between them the bases of the ' $t$ ' value. Because the ' $t$ ' value was 0.21 which is low the value base 0.05 .

(f) Results of attitude of the rural students on the bases of the mean S.D. and 't' value.

The mode of the rural male and female students towards English curriculum was 147.50 and 141.31.

The comparison of the ' $t$ ' value of the rural male and female students towards English curriculum showed that there was difference in the attitude. Because ' $t$ ' value was 2.17 was more than value base 0.05 .

(g) Results of attitude of the urban students on the bases of the Mean, S.D. and ' $t$ ' value.

The mode of the urban male and female students towards English curriculum was 145.50 and 142.50.

The comparison of the ' $t$ ' value of the urban male and female students towards English curriculum showed that there was no difference in the attitude. Because ' $t$ ' value was 1.01 and it was less than value base 0.05 .

(H) Difficulties in the way of the students during the learning of the English curriculum.

There are six types of difficulties faced by the students. More than $89.06 \%$ of students face difficulty in reading of the text book.

More than 59.38\% students face difficulty because of the teaching methods of the teachers.

\section{SUGGESTIONS}

Suggestions for the teachers

(A) The teacher should use more and more new educational techniques and methods during teaching.

(B) The teacher should use more and more helping tools to clear the subject matter.

(C) The teacher should use words during the classroom teaching.

(D) The behavior of the teacher should be equal toward the all students.

\section{Suggestions for the students.}

The students should take more and more interest in learning English language.

\section{CONCLUSION}

The main aim of the present research paper to do a study on an interest and attitude of the students of Khargone taluka's urban and rural high secondary schools in English curriculum. In the present research paper the investigator tried the compare the attitude of rural and urban students toward English curriculum.

The researcher hope that in the suggestions and the results will be helpful for the development of the situation of the English curriculum in schools at the present time.

\section{REFERENCES}

[1]. Brahmbhatt, J.C., A Study of Pupa Ration of Language Programmed in English. Data, C., Effect of Maximizing Control Clues. A Pragmatic Study, Ph.D. FLT, CIEFL, 1985.

[2]. "Agarwal, M., A Factorial Study of Attitude of Students towards Some Social Problem, Ph.D Edu. Jammu U., 1984 Setee, E.D and Ross, E.L, (1987)

[3]. Ravindra Nath Tegore "A case Study in Applied Education in rural India" Community Development Journal, 22 (2): 120-129, Oxford University Press.

[4]. NCTE 2007, State Curriculum Framework, Bhopal.

[5]. NCERT, 2005, National Curriculum Framework-2005, New Delhi India.

[6]. Jai Prakash, A comparative Study of Urban, Rural and Tribal Higher Secondary Students of Madhya Pradesh with the Reference to their General Mental Ability and Interest Pattern, Dept. of Pay, Sag. U., 1972 (ICSSR financed)-2

[7]. Joseph, K.S., Enrolling a Strategy for Teaching English Grammar at High School Level, Ph.D. Edu MSU 1983-4

[8]. Kamlesh, A., A comparative Study of Self Concept, Adjustment, Interest and Motivation among the Scheduled Caste and Non Schedule Caste Students. MD. Edu., Kan. O. 1981-3. 